Milorad Pavlović, dipl. inž. Gordana Jurin, dipl. inž. Tehnički opitni centar Beograd

\section{PRIMENA SISTEMA ZA MONITORING BUKE I MATLAB-a ZA PRORAČUN NIVOA AVIONSKE BUKE}

UDC: $629.735: 534.83 .08]: 004.4$

Rezime:

$U$ radu je prikazan način primene sistema za monitoring buke, terminal NMT 3637B $i$ softver 7802, firme Brüel \& Kjoer, u procesu sertifikacije mlaznih aviona, prema ICAO, standardu Annex 16 i algoritam za proračun EPNL nivoa buke (Effective Perceived Noise Level), koji je kreiran u okruženju MatLab. Ovim softverom sublimirani su svi potrebni ulazni podaci, akustički i neakustički, radi dobijanja traženog nivoa i svih međurezultata neophodnih za formiranje konačnog izveštaja koji se dostavlja vazduhoplovnim vlastima.

Ključne reči: mlazni avion, avionska buka, merna oprema, softver.

\title{
NOISE MONITORING SYSTEM AND MATLAB APPLICATION FOR AIRCRAFT NOISE LEVEL CALCULATION
}

Summary:

This paper presents the use of noise monitoring system, terminal NMT $3637 \mathrm{~B}$ and software 7802, Brüel \& Kjoer in process of jet aircraft noise certification according to standard ICAO Annex 16 and the algoritam for calculating EPNL noise level (Effective Perceived Noise Level) that we created in MatLab environment. This software sublimated all necessary input parameters, acoustic and non acoustic in purpose of getting final result and intermediate data. Those data are important for reporting to the certificating authority.

Key words: jet aircraft, aircraft noise, measuring equipment, software.

\section{Uvod}

Složenost postupka određivanja nivoa spoljašnje buke mlaznih aviona za potrebe sertifikacije prvenstveno se ogleda u broju ulaznih podataka, dužini njihovog vremenskog zapisa, kao i načinu merenja i obrade. Složenosti postupka doprinosi i broj mernih mesta i merenja. Uslovi i metodologija merenja definisani su međunarodnim standardom ICAO, Annex 16 [1].

Nivo buke ovih aviona izražava se u EPN dB jedinicama i daje se za referentne letne $i$ atmosferske uslove. Ulazni podaci za proračun su akustički podaci, od- nosno buka testiranog aviona i šum ambijenta, putanja leta, parametri leta i meteorološki podaci.

Akustički podaci, odnosno nivoi zvučnog pritiska po tercama, čije su centralne frekvencije od $50 \mathrm{~Hz}$ do $10 \mathrm{kHz}$, snimaju se korakom $0,5 \mathrm{~s}$. Sinhronizovano sa ovim podacima snimaju se i parametri leta i pozicija aviona na putanji. Potrebna dužina vremenskog zapisa za obe vrste merenja po mernom mestu je oko 1 minut.

Referentne uslove definišu atmosferski pritisak od 1013,25 mbar, temperatura $25^{\circ} \mathrm{C}$, relativna vlažnost $70 \%$, vetar $0 \mathrm{~m} / \mathrm{s}$, standardizovane putanje poletanja 
i sletanja. Odstupanje od ovih uslova ima za posledicu promenu uslova prostiranja zvučnih talasa, zbog promene atmosferskog i propagacionog slabljenja i perioda izloženosti buci.

Referentne putanje poletanja i sletanja određuju se na osnovu podataka datih u standardu i uputstvu pilotu za upravljanje avionom.

Imajući u vidu složenost merenja, kao i to da je potrebno najmanje po šest merenja na tri definisane lokacije, dve u fazi poletanja (merna mesta K1 i K2) i jedna u fazi sletanja (merno mesto K3), za akviziciju i obradu svih predviđenih podataka neophodna je savremena merna oprema sa računarskom podrškom, visoke tačnosti, koja omogućava pristup rezultatima odmah nakon završenog opita.

$\mathrm{U}$ radu su istaknute prednosti upotrebljene merne opreme, kratak pregled algoritma za proračun nivoa avionske buke - EPNL i njegova izrada u MatLab okruženju.

\section{Avionska buka}

Deskriptor avionske buke je efektivni nivo percipirane buke - EPNL (Effective Perceived Noise Level) izražen $u$ EPN dB jedinicama. Ovaj nivo predstavlja meru subjektivnog doživljaja avionske buke u koji su, osim jačine, inkorporirani bučnost, iritirajuće dejstvo i trajanje. Nivo EPNL određuje se proračunom PNL nivoa (Perceived Noise Level, jedinica PN dB), PNLT nivoa (Perceived Noise Level Tone-Corrected, jedinica TPN dB) i perioda izloženosti buci u to$\mathrm{ku}$ preleta aviona. Nivo PNL uzima u obzir varijaciju čujnosti u funkciji frekvencije, PNLT doprinos tonova ili diskretnih frekvencija često prisutnih $\mathrm{u}$ kompleksnom zvuku kao što je avionska buka, a EPNL i period izloženosti buci. U proračunu njihovih vrednosti figurišu nivoi buke izmereni na svakih 0,5 sekundi u 24 tercna opsega, u opsegu frekvencija od $40 \mathrm{~Hz}$ do $11,2 \mathrm{kHz}$.

\section{Merna oprema}

Za akviziciju i obradu akustičkih podataka odabran je sistem za monitoring buke, firme Brüel \& Kjær. Sistem čine terminal NMT 3637B i softver ANMS 7802. Osnovna namena ovog sistema je kontrola nivoa buke u životnoj sredini, $u$ dužem periodu. Postavljaju se u okolini aerodroma, prometnih saobraćajnica, železničkih pruga i drugih bučnh lokacija u naseljenim mestima. Podatke sa permanentnih terminala server preuzima u korisnički definisanim intervalima, putem modema i javne telefonske mreže ili LAN komunikacije. Svi podaci se sortiraju i storniraju u sistemske baze podataka i trenutno su dostupni za prezentaciju u tabelarnom i grafičkom obliku, kao i u obliku izveštaja za događaj - event: 1 sat, 24 sata, 1 mesec snimanja, kratak izveštaj, spektar na $1 / 2 \mathrm{~s}$, kalibracioni izveštaj). Navedeni izveštaji sadrže i statističke pokazatelje.

Dinamički opseg merenja je $110 \mathrm{~dB}$, tako da je moguća akvizicija signala nivoa do $140 \mathrm{~dB}$ kada se koristi mikrofon 4189. Omogućava snimanje Leq nivoa (ekvivalentni kontinualni nivo buke) ili SPL (Sound Preasure Level - nivo zvučnog pritiska) na A ili linearnoj frekvencijskoj skali, sa SLOW, FAST, IMPULS ili PEAK detektorom. Postoji mogućnost definisanja minimalnog nivoa (SETL, NSETL i SENL) i minimalnog perioda trajanja događaja kao uslova za formiranje 
zvučnog zapisa događaja (wav fajl) na hard disku sistema za memorisanje.

Terminal NMT 3637B je autonoman u pogledu napajanja i predviđen je za duži rad na otvorenom prostoru, do 6 sati, gde je temperatura između $-30^{\circ} \mathrm{C} \mathrm{i}+50^{\circ} \mathrm{C}$ i maksimalnom relativnom vlažnošću od $90 \%$ na $+30^{\circ} \mathrm{C}$. Kalibracija se može izvršiti pomoću pistonfona ili akustičkog kalibratora.

Razlog za izbor navedenog sistema je činjenica da on omogućava merenje, anali$\mathrm{zu}$ i zapis ukupnog i tercnih nivoa $\mathrm{u}$ realnom vremenu, a podaci su dostupni odmah nakon završetka opita. Zahvaljujući autonomnosti u pogledu napajanja i kapacitetu hard diska, opit može da traje i do 6 sati.

U sklopu terminala NMT 3637B nalaze se mikrofonska jedinica za spoljašnju upotrebu, analizator nivoa buke i sistem za memorisanje podataka (sl. 1).

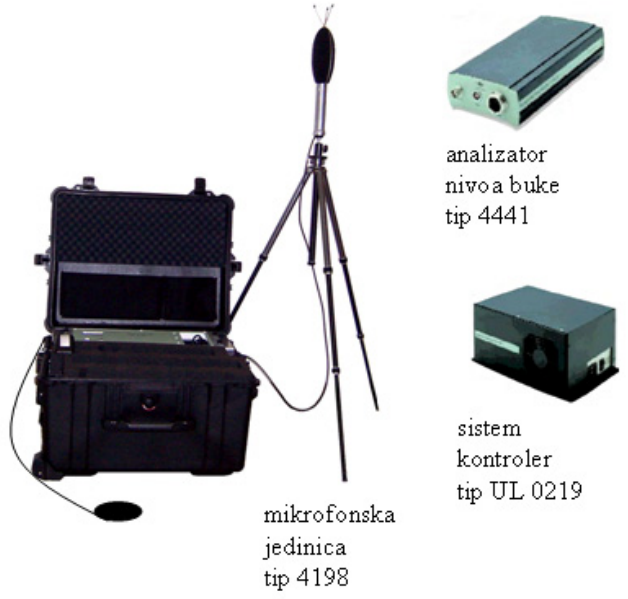

Sl. 1 - Terminal za monitoring buke NMT 3637B

Mikrofonsku jedinicu za spoljašnju upotrebu 4198 čine: mikrofon 4189, pretpojačavač 2669 C, štitnik od vetra, kiše i ptica UA1404, stalak za mikrofon UA 0801 i kabl dužine 10 m AO 0415. Mikrofon je od $1 / 2$ ", free-field, kondenzatorski, prepolari- san $(0 \mathrm{~V})$, opsega od $6 \mathrm{~Hz}$ do $20 \mathrm{kHz}$ i osetljivosti $50 \mathrm{mV} / \mathrm{Pa}$. Pretpojačavač je od 1/2", sa jedinicom za CIC kalibraciju (Charge Injection Calibration).

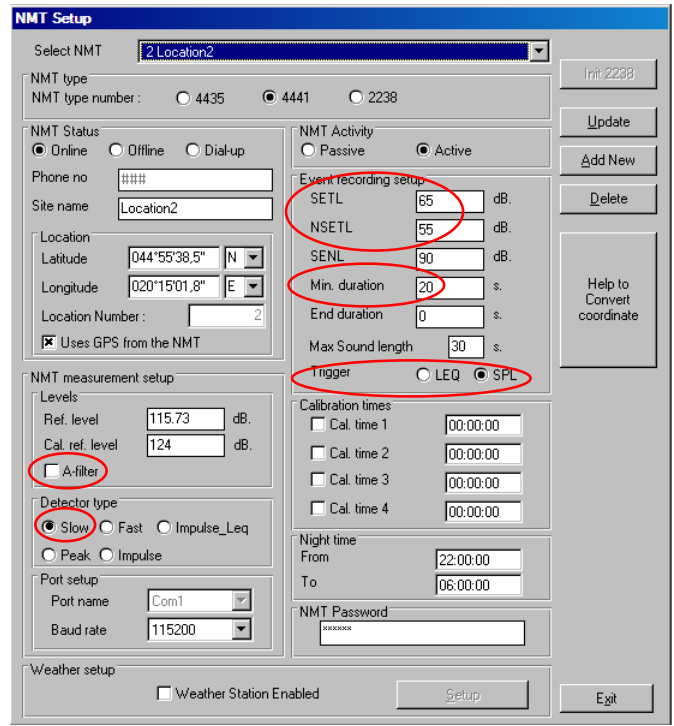

Sl. 2 - Softversko definisanje parametara snimanja buke

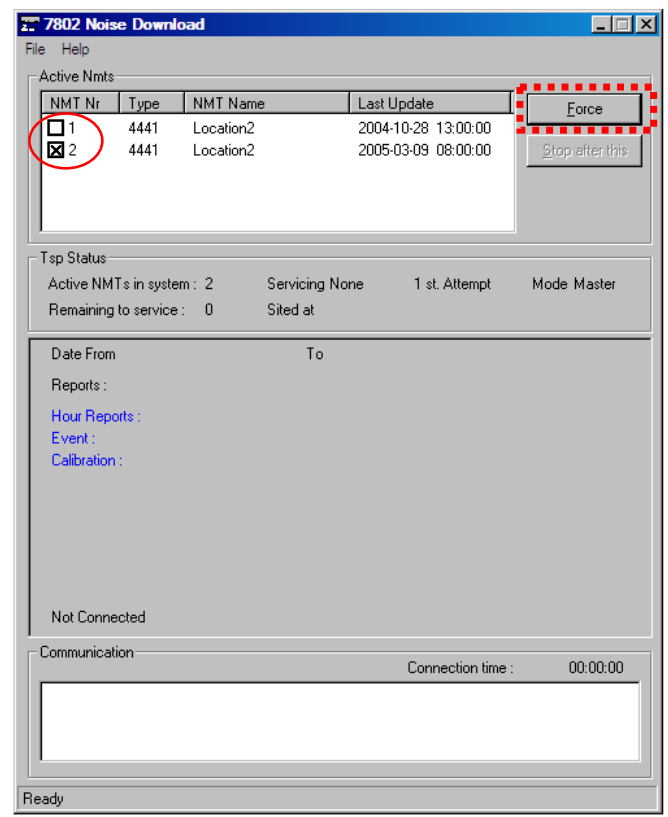

Sl. 3 - Softversko aktiviranje procedure prenosa podataka, NMT-PC-NMT 
Sistem za analizu čini analizator nivoa buke 4441. Analiza signala je oktavna ili tercna sa korakom $0,5 \mathrm{~s}$ ili $1 \mathrm{~s}$, u opsegu od $12 \mathrm{~Hz}$ do $20 \mathrm{kHz}$ i vrši se sa digitalnim filtrima, klase 1. Brzina semplovanja je $48 \mathrm{kHz}$, a referentno slabljenje $0 \mathrm{~dB}$.

Sistem za memorisanje podataka je industrijski PC Pentium sa hard diskom od $20 \mathrm{~GB}$ i instalisanim softverom ANMS 7802 (Aircraft Noise Monitoring Software). Ovaj softver instalisan je i na notebook računaru i koristi se za konfigurisanje NMT (sl. 2), sortiranje i storniranje podataka merenja u sistemske baze na disku računara NMT, prenos istih sa NMT na notebook računar radi pregleda, prezentacije ili dalje obrade u nekim drugim programima (sl. 3). Tačnost iščitavanja podataka je $0,1 \mathrm{~dB}$. Pored navedenih funkcija omogućeno je i vizuelno praćenje promene nivoa buke u realnom vremenu (sl. 4)

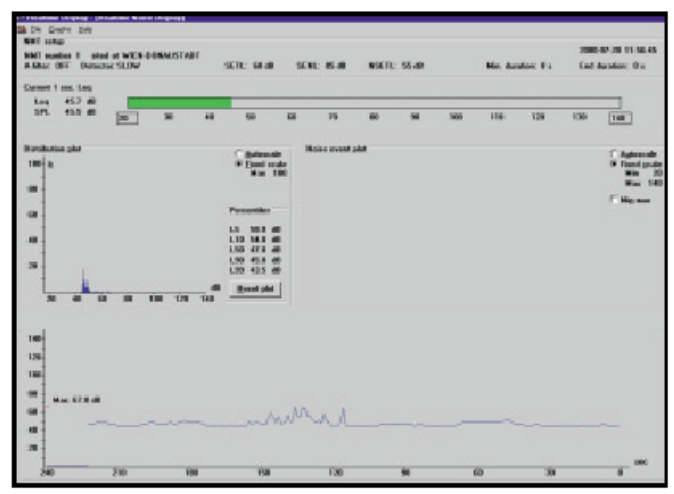

Sl. 4 -Vizuelizacija promene nivoa buke u realnom vremenu

Neophodni meteorološki podaci preuzimaju se od aerodromske meteorološke službe, a podaci za poziciju aviona na putanji sa GPS koji se ugrađuju na testirani avion. Za ove potrebe koristi se diferencijalni GPS - GPS System 1200, firme Leica (sl. 5 i 6).

\section{Algoritam za proračun EPNL}

Ulazni podaci za proračun EPNL su tercni podaci za avionsku buku i ambijentalni šum i sledeći neakustički podaci: pozicija aviona na putanji, putna brzina, koordinate mernog mesta, temperatura $\mathrm{i}$ relativna vlažnost vazduha, u uslovima merenja i referentnim uslovima. Potrebna merna oprema i scenario merenja prikazani su na sl. 7.

Akustički podaci, odnosno nivoi zvučnog pritiska po tercama, čije su centralne frekvencije od $50 \mathrm{~Hz}$ do $10 \mathrm{kHz}$ snimaju se SLOW dinamičkom karakteristikom detektora i linearnom frekvencijskom skalom, sa korakom od 0,5 s. Sinhronizovano sa podacima za avionsku buku snima se i pozicija aviona na putanji. Potrebna dužina vremenskog zapisa za obe vrste merenja je oko 1 minut.

Ambijentalni šum snima se neposredno pre i nakon svakog prolaza-preleta mernog mesta u trajanju od minimalno $10 \mathrm{~s}$, a optimalno $30 \mathrm{~s}$. U postupku proračuna koriste se usrednjeni tercni nivoi izraženi u decibelima.

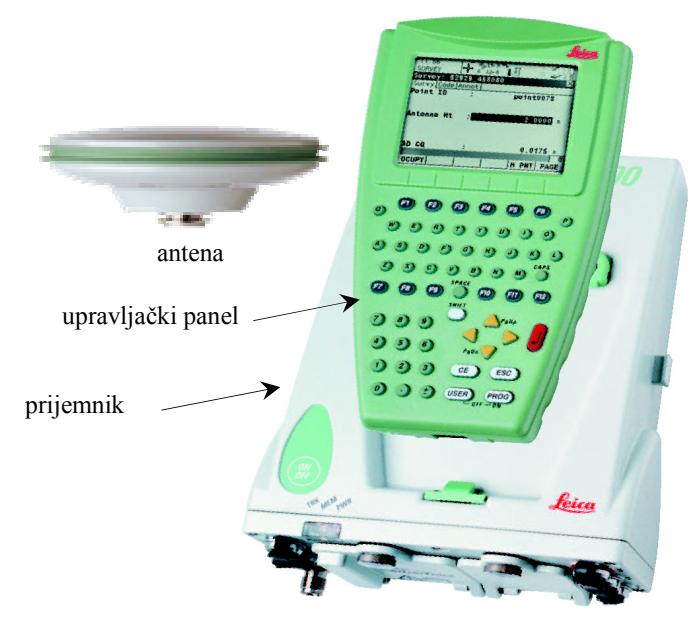

Sl. 5 - GPS System 1200, Leica 


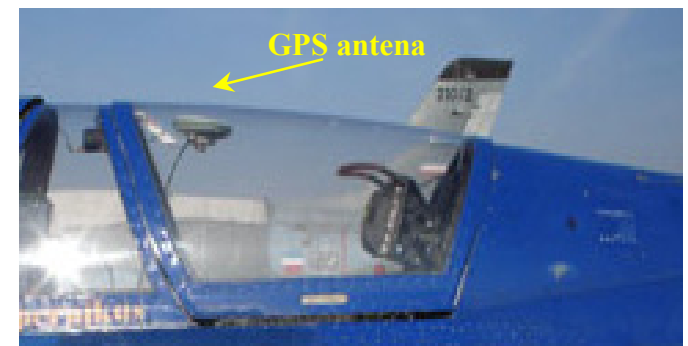

Sl. 6 - Antena GPS System 1200, Leica na avionu $G-2 A$

Proračun nivoa EPNL može se vršiti po simplified ili integrated metodi. Po prvoj metodi koja je u ovom radu prezentovana, svođenje na referentne operativne i atmosferske uslove vrši se samo u tački detekcije maksimalne buke, nivo PNLT $_{\text {max }}$, a po drugoj u svim intervalima izračunatog nivoa PNLT(k).

Prema simplified metodi prvo se izračunava EPNL u uslovima merenja, pri čemu su prethodno uklonjeni efekti šuma pozadine ukoliko postoje - EPNL ${ }_{m}$, a zatim $u$ referentnim uslovima $-\mathrm{EPNL}_{\text {ref. }}$.

Proračun EPNL u uslovima merenja i u referentnim uslovima dat je relacijama (1) i (2), respektivno.

$$
\begin{aligned}
& E P N L_{m}=P N L_{\text {max }}+C+D \\
& E P N L_{r e f}=E P N L_{m}+\Delta_{1}+\Delta_{2}
\end{aligned}
$$

gde je:

$\mathrm{PNL}_{\max }$ - maksimalna vrednost PNL nivoa,

$\mathrm{C}$ - faktor tonske korekcije,

D - korekcioni faktor za izloženost buci u uslovima merenja,

$\Delta_{1}$ - korekcija za meteorološke i propagacione uslove, $\mathrm{i}$

$\Delta_{2}$ - korekcija za promenu perioda izloženosti buci.

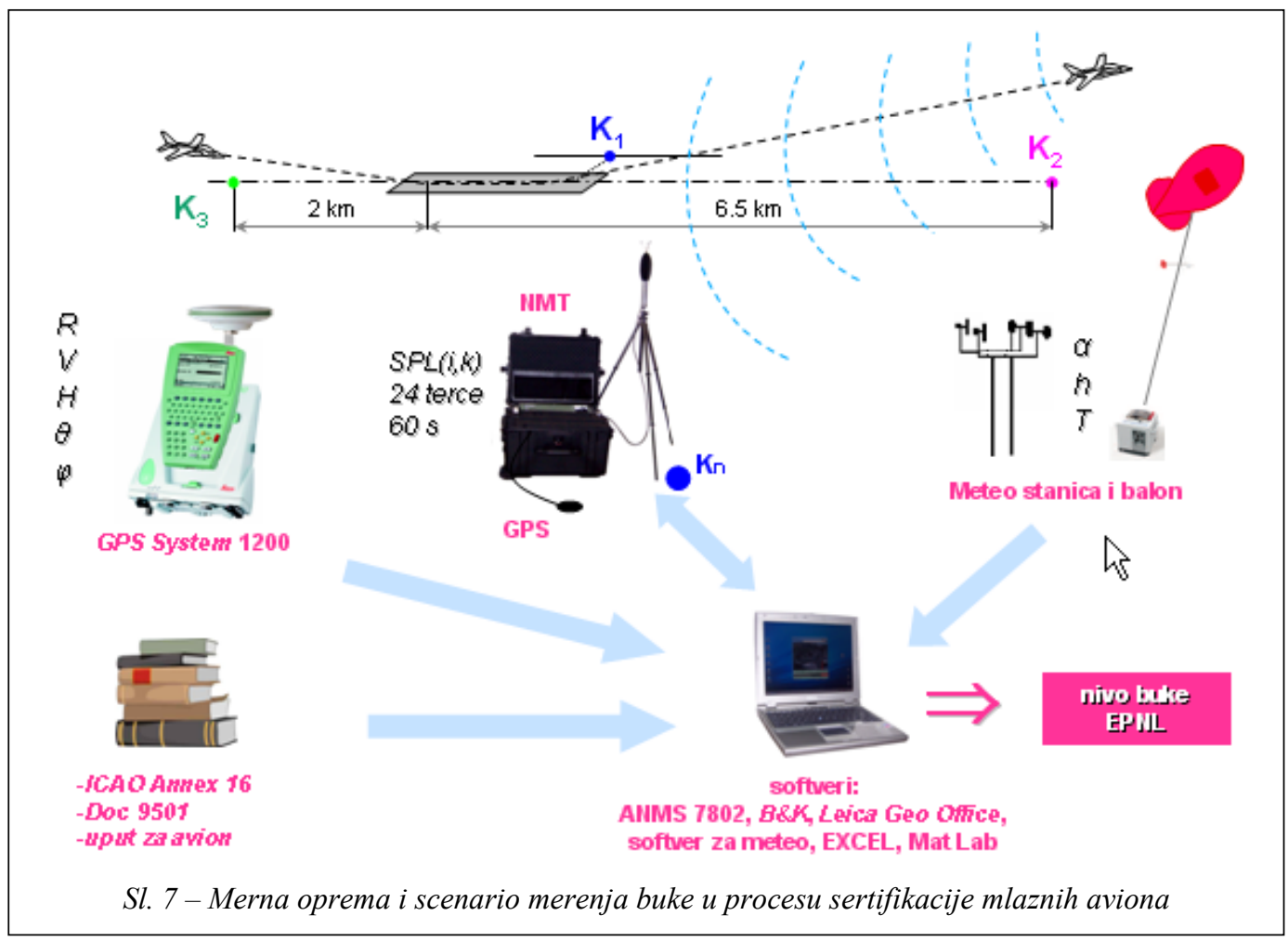


Prvi korak pre proračuna $E P N L_{m}$ je validacija uslova i podataka merenja. Proverava se koeficijent atmosferskog slabljenja na $8 \mathrm{kHz}$, koji mora biti manji od $12 \mathrm{~dB} / 100 \mathrm{~m}$, zatim nivo ambijentalnog šuma, koji mora biti minimalno 20 PN dB ispod maksimuma avionske buke i, na kraju, tercni nivoi avionske buke, koji moraju biti bar $3 \mathrm{~dB}$ iznad srednje vrednosti ambijentalnog šuma u posmatranoj terci, za sve zapise, u periodu 10 $\mathrm{dB}$ ispod $\mathrm{PNLT}_{\max }$. U slučaju nezadovoljavanja trećeg uslova postoji mogućnost korekcije primenom metoda frekvencijske ili vremenske ekstrapolacije radi otklanjanja njegovog efekta. Međutim, to nameće dodatne uslove validacije merenja, o čemu je detaljno dato u [2] i [4]. Pri primeni navedenih korekcionih metoda potrebni su i podaci o atmosferskom slabljenju i rastojanju avion - mikrofon.

\section{Softver za proračun EPNL u MatLab okruženju}

U okviru Brüel \& Kjær softvera ANMS 7802 proračunavaju se i nivoi PNL, PNLT i EPNL sa korakom od 0,5 ili 1 s. Međutim, ove vrednosti za korisnika imaju samo informativni karakter, jer proračunom nisu obuhvaćene korekcije koje standard ICAO, Annex 16 propisuje. Zbog toga je za proračun EPNL izrađen softver u paketu MatLab.

Razlozi za primenu paketa MatLab su višestruki. Prvo, ovaj paket nudi izvanredne matematičke mogućnosti, drugo, ima relativno dobru grafičku vizuelizaciju rezultata, treće, lako se programira (kreiranje m fajlova) i, četvrto, instalacija je podržana na računarima različitih konfiguracija i operativnog sistema.
U našem slučaju, proračun EPNL nivoa i potrebnih međurezultata za formiranje izveštaja vazduhoplovnim vlastima vrši se u programskom paketu MatLab 7.0 na notebook računaru Dell Latitude D400 (procesor: Intel Pentium M $1.4 \mathrm{GHz}, \mathrm{RAM}$ : 1GB) sa operativnim sistemom Microsoft Windows XP.

Izgled osnovnog prozora MatLab 7.0 nakon startovanja aplikacije prikazan je na sl. 8. U toolbar-u za podešavanje tekućeg direktorijuma (Current Directory), uneta je putanja foldera sa namenskim potprogramima, tj. funkcijama. Isti folder koristi se za smeštaj dela potrebnih ulaznih podataka, kao i samih rezultata. Proračun za svako od mernih mesta $\mathrm{K} 1, \mathrm{~K} 2 \mathrm{i}$ K3 aktivira se unosom u komandni prozor (Command Window) naredbe run bukaK1, run bukaK2 i run bukaK3, respektivno. Razlog za odvajanje programa za svako merno mesto uslovljen je različitim podacima za položaj mernog mesta $i$ putanje leta aviona u referentnim uslovima, kao i različitim postupcima proračuna rastojanja mikrofon - avion.

Aktiviranje navedenih $\mathrm{m}$ fajlova, pored naredbi za učitavanje podataka i snimanje rezultata, pokreće i odgovarajući niz funkcija. U opticaju su sledeće: F1 - validacija merenja, utvrđivanje prisustva efekata ambijentalnog šuma i rekonstrukcija maskiranih podataka, F2 - proračun EPNL nivoa u uslovima merenja kada ne postoji uticaj ambijentalnog šuma, F3 - proračun EPNL nivoa u uslovima merenja kada je uklonjen efekat ambijentalnog šuma, F4 - određivanje položaja i brzine aviona u trenutku maksimuma buke u uslovima merenja i referentnim uslovima, F5 - proračun korekcija 


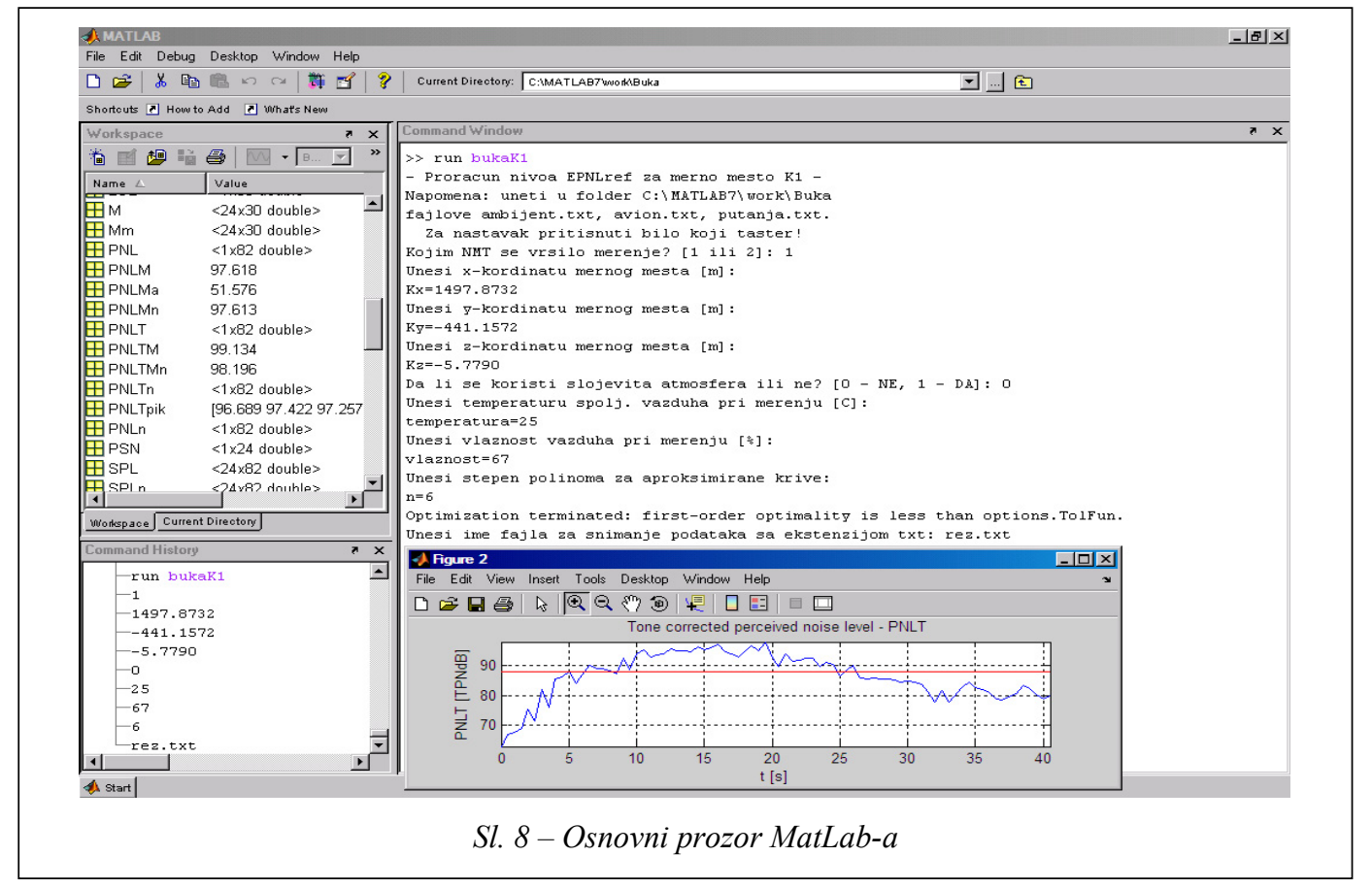

$\Delta_{1}$ i $\Delta_{2}$ za svođenje rezultata na referentne uslove pri odsustvu efekata ambijentalnog šuma i F6 - proračun korekcija za svođenje rezultata na referentne atmosferske $\mathrm{i}$ letne uslove posle izvršene rekonstrukcije maskiranih podataka.

Za proračun koeficijenata atmosferskog slabljenja ili grafički prikaz međurezultata $\mathrm{u} \mathrm{m}$ fajlovima pozivaju se $\mathrm{i}$ funkcije Crtanje i AtmSl. Sam izbor funkcija u proračunu nivoa buke uslovljen je međurezultatima, što je ilustrovano kroz dijagram toka na sl. 9. Nakon prihvatanja ulaznih podataka, trajanje proračuna za svako od mernih mesta ne prelazi nekoliko sekundi.

Izlazni podaci unose se delom preko tastature u komandni prozor tokom izvršenja samih potprograma (izbor mernog sistema, koordinate mernog mesta, temperatura, relativna vlažnost, ime fajla za smeštanje rezultata, stepen polinoma za aproksimaciju putanje leta), a delom preko unapred formiranih txt fajlova. Za svako merno mesto i svaki pojedinačan let oni nose oznake avion.txt, ambijent.txt $i$ putanja.txt $i$ pre proračuna smeštaju se u pomenuti tekući direktorijum. Prvi sadrži SPL vrednosti snimljene buke, drugi SPL vrednosti ambijentalnog šuma, a treći parametre putanje aviona, tj. vreme, prostorne koordinate (x, y i z) i brzinu u uslovima merenja. U programu se koriste i podaci za poziciju i brzinu aviona na putanji za referentne uslove. Pri promeni tipa aviona, ovi podaci moraju se ažurirati, zamenom txt fajlova refK1.txt, refK2.txt i refK3.txt u radnom folderu sa novim. Slično važi i za promene korekcionih faktora za mikrofon, kada se vrši zamena fajlova NMT1cfr.txt i NMT2cfr.txt. 


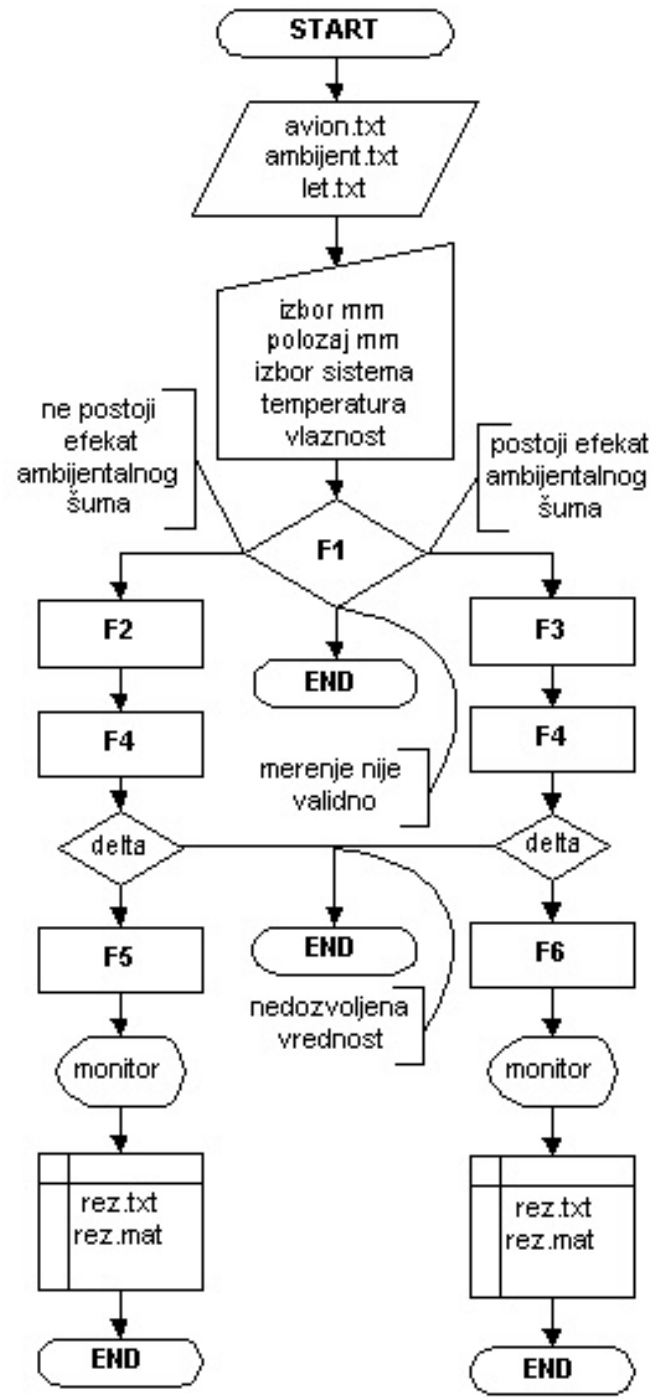

Sl. 9 - Dijagram toka pri proračunu EPNL nivoa

Rezultati se automatski beleže u radni folder, generisanjem dva fajla istog imena, ali različite ekstenzije. Prvi je txt formata i sadrži najbitnije rezultate, dok fajl sa ekstenzijom mat sadrži sve formirane promenljive u proračunu, kao i bitne međurezultate.

Pri svakom sledećem startovanju proračuna, pre upotrebe novih ulaznih podataka, potrebno je izbrisati radni prostor (Workspace) i komandni prozor.
U procesu formiranja opisanog softvera, testiranja su izvršena u određenim fazama na osnovu poređenja rezultata sa podacima iz standarda za poznati set ulaznih podataka. Sledeći korak u njegovom daljem razvoju je formiranje baze podataka koje identifikuju tip aviona u referentnim uslovima i realizaciju grafičkog interfejsa (GUI) radi postizanja bolje korisničke transparentnosti.
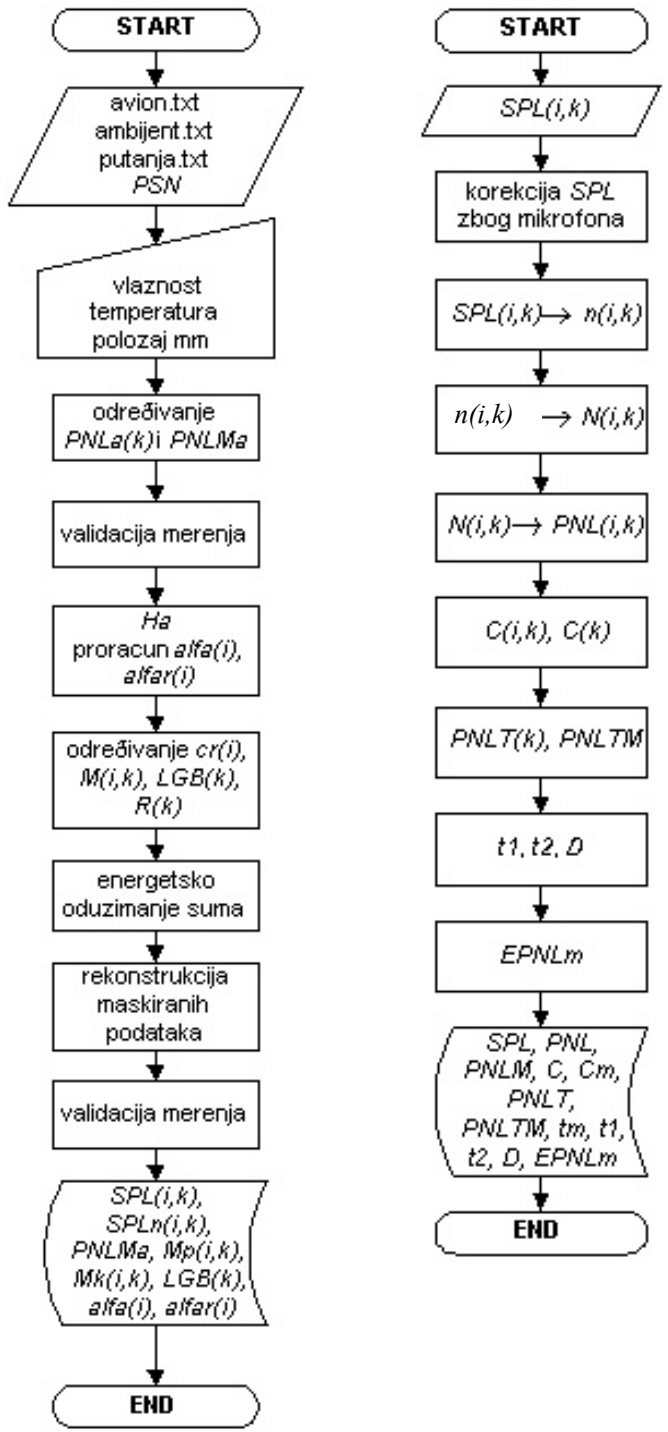

Sl. 10 - Funkcije F1 i F2 


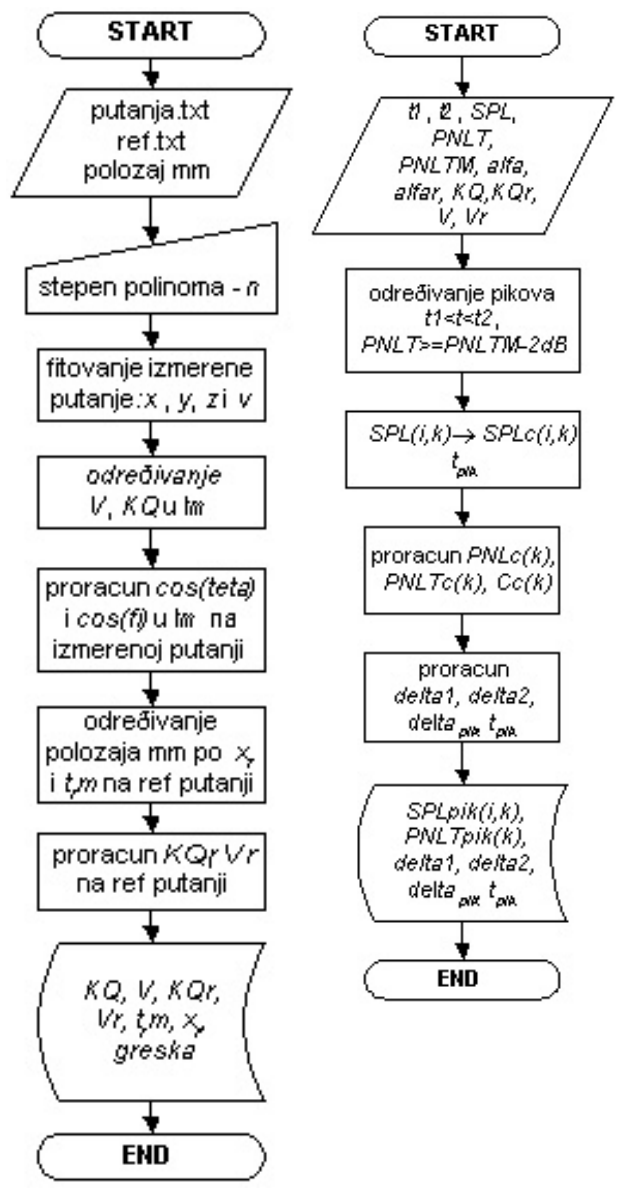

Sl. 11 - Funkcije F4 i F5
Na sl. 10 i 11 prikazani su osnovni koraci $\mathrm{u}$ realizaciji prethodno navedenih funkcija F1, F2, F4 i F5.

\section{Zaključak}

$\mathrm{U}$ radu je istaknuta neophodnost upotrebe savremene merne opreme sa računarskom podrškom visoke tačnosti, koja omogućava pristup rezultatima odmah nakon završenog opita, kao i neophodnosti realizacije namenskog softvera radi povećanja efikasnosti merenja i skraćenja vremena obrade i dobijanja konačnih rezultata

Literatura:

[1] ICAO Annex 16, Environmental Protection, Volume I Aircraft Noise, Third Edition, 1993.

[2] Doc. 9501 - Environmental Tehnical Manual on the Use of Procedures in the Noise Certification of Aircraft - ICAO Committee on Aviation Environmental Protection, 1993.

[3] Jurin, G., Pavlović, M.: Određivanje buke radi sertifikacije mlaznih aviona, Vojnotehnički glasnik, str. 36-50, januar februar 2005.

[4] Jurin, G., Pavlović, M.: Avionska buka i uticaj ambijentalnog šuma na tačnost merenja, Konferencija za ETRAN, Čačak, sveska II, str. 401-404, jun 2004. 